\title{
Mitigation of interference from ECG: A Review
}

\author{
Shifa Kaushal \\ School of Electronics and Electricals Engineering \\ Lovely Professional University, Phagwara
}

\author{
Amanjot Singh \\ School of Electronics and Electricals Engineering \\ Lovely Professional University, Phagwara
}

\begin{abstract}
ECG (Electrocardiography) presented the electrical activity of heart and it gives us the information about heart rate. There are various types of artifacts which are inherently added to the ECG and due to which the important information of patient's health status can be lost. During the analysis of ECG data the noise reduction in ECG is one of the important problem. As the ECG plays an important role in analyzing the health status of humans, hence ECG needs an effective denoising technique. In this paper, review on various methods of mitigation of noise from ECG signal has been done.
\end{abstract}

\section{Keywords}

Electrocardiogram (ECG) signal, Electromyography (EMG), WT, LMS, NLMS, RLS

\section{INTRODUCTION}

Electrocardiogram (ECG) is trace of the electrical signals produced by the heart of patient. The ECG signal is normally in the range of $2 \mathrm{mV}$ and needs a recording bandwidth of 0.1 to $120 \mathrm{~Hz}$ [1]. The ECG is obtained by placing the electrodes at the consistent locations on the skin of the patient [2]. The ECG signal and heart rate tells about the health status of human heart. Any inconsistency in heart rate or rhythm or change in the pattern of ECG signal indicates the health problem of heart. It is observed and identified the nature of problem by the analysis of the obtained ECG waveform. The amplitude and duration of wave contains the useful information about the nature of disease related to heart of the patient.

During acquisition, obtained ECG signal corrupted by the various types of artifacts. Some of them are power line interference, electrode contact noise, noise due to random movement of patient, repirational movements, electromyography (EMG) noise and instrumentation noise. These artifacts degrades the signal quality and frequency resolution of obtained ECG signal containing important information. For efficient analyzing of ECG signal, it is essential to remove these artifacts creating disturbances in ECG signal and improve its accuracy and reliability. Many methods have been implemented to remove these artifacts from noisy ECG signal. One of the basic method is to pass the ECG signal from high pass, low pass and notch filter (band stop filter with narrow stop band and having high Q-factor). Notch filter is used to reduce the power line interference. But these filters are static in nature and these also remove some important frequency components near to the cut off frequency. Instrumentation noise cannot be reduced by the static filters because they are having fixed filter coefficients. It is difficult to reduce that noise by these fixed filter coefficients because the noise is having the time varying behavior which is not exactly known. The limitations of these static filters can be overcome by different adaptive filtering methods.

The ECG signals obtained from the different patients are of the similar forms but the ECG of individual patient is different. The signal processing for baseline correction and noise suppression is basically the first step in the analysis of ECG signal [5].

ECG signal consist of three parts i.e. $\mathrm{P}$ wave, a QRS complex and a $T$ wave. ECG signal is periodic in nature and also satisfies the Dirichlet's conditions[4].

It may be observed from fig 1 that a single cycle of ECG signal is a combination of triangular wave and sinusoidal waveform[5].

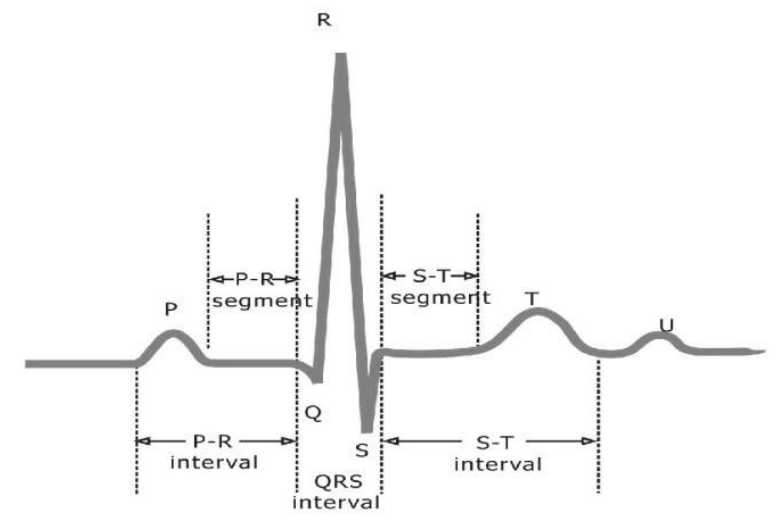

Fig 1 Basic representation of ECG signal.

\section{LITERATURE REVIEW}

Many researchers have worked on the removal of power line interference from ECG signal. There are many methods have been suggested or implemented.

R. Acharya, J. S. Suri, J. A.E. Spaan and S .M. Krishnan (2007). In this paper, the power line interference removed from the obtained ECG signal by the non linear adaptive method. Many methods have been implemented in this work and power line interference has removed by the non linear adaptive methods [3].

Prakruti J. Joshi, Vivek P. Patkar (2013).In today's scenario many of the ECG obtaining instruments are based on the analog recording circuitry. Due to which noises from various sources are introduced to the ECG signal. Sometimes the power of noise becomes more the original signal. In this paper, these noises that basically corrupt the ECG signal are identified and attempt is made to get rid of such noises. A new filter called as moving averaging filter is implemented in this paper which has shown very good efficiency in smoothing out the waveform and suppressing $50 \mathrm{~Hz}$ power line noise from the original ECG signal [5].

K. Satyanarayana, A.D.Sarma, P.Naga Praveen, M. Malini, D. Krishna Reddy (2013).The health status of an accident victim or critically ill patient needs to be continuously accessed on the way to the hospital. During this golden period, the electrocardiogram (ECG) gives the vital information of health status of the patient. The recording of ECG signal is badly affected by the noise and interference making the diagnosis 
difficult. In this paper, an effort is made to recognize a suitable technique among various methods like wavelet transform, least mean squares, normalized least mean squares and recursive least squares for noise reduction. These techniques have been implemented on the ECG signal and the comparison is obtained. The results thus obtained are encouraging[6].

Galya Georgieva-Tsaneva (2013).In this paper, a new adaptive thresholding method for removing the noise from ECG signals using wavelet transform has been proposed. An improvement of the traditional denoising technique has been projected by implementing a new sub band dependent threshold. The proposed algorithm has been evaluated with ECG signals with added ordinary Gaussian noise. The obtained results show that the projected algorithm for mitigation of noise could be applied to the ECG signals.[7].

Akanksha Deo, DBV Singh, Manoj Kumar Bandil, Dr. A K Wadhwani(2013). ECG signal is a very resourceful tool for detection of heart diseases. But during recording of the ECG signal, it gets corrupted by the various noise signals. These noise signals are also called as artifacts and it mislead the analysis of heart.To evade this difficulty caused by the artifacts, elimination of these artifacts has become necessary. There are various methods to overcome this problem. In this paper, one more method is presented which is patch based and used from rejection of artifacts from the ECG signal. In this work, least mean square (LMS) algorithm and patch based has been implemented for removing the artifacts from the ECG signal.[8].
E.-S.(2011).This paper introduces a convincing mixture plan of genetic algorithm (GA) and wavelet transform (WT) for removing noise from ECG signals corrupted by the non stationary noises. Primarily connected a wavelet denoising in noise reduction of multi channel high resolution ECG signals. Specifically, the impact of the selection of wavelet function and the choice of decay level on productivity of methodology of removing the noise was acknowledged. Purpose of an appropriate wavelet denoising parameters is basic for the execution of ECG signal filtration in wavelet domain. Accordingly, in our noise removal approach the genetic algorithm has been used to select the required wavelet denoising parameters which timely expand the accomplishment of ECG filtration. The test results reveal that the presented intersect plan utilizing GA has obtain preferable implementation over the other reported wavelet thresholding algorithms and also the nature of the denoised ECG signal by this method is more appropriate for the medical analysis.[9]

H. A.Kestler,M.Haschka,W.Kratz, F. Schwenker, G. Palm,V.Hombach, and M. Hoher (1998).In this paper, the authors implemented a combination of the discrete wavelet transform and the Wiener filter to the noise reducing of high resolution ECG signals. The methodology is appropriate at all squares sense, in that the method divides the signal from additive noise. The comparison between this methodology and the popular de-noising algorithm by Donoho on artificially generated signals and on a high resolution ECG signal corrupted by noise was observed, so that high resolution ECG signals can easily denoised.[10]

\begin{tabular}{|c|c|c|c|c|c|c|}
\hline $\begin{array}{l}\text { Sr. } \\
\text { no }\end{array}$ & $\begin{array}{l}\text { Author's } \\
\text { name and } \\
\text { place }\end{array}$ & $\begin{array}{l}\text { Year of } \\
\text { Publicatio } \\
n\end{array}$ & Topic & Approach & Results & $\begin{array}{l}\text { Future scope \& } \\
\text { limitations. }\end{array}$ \\
\hline 1 & $\begin{array}{l}\text { H. } \\
\text { A.Kestler,M. } \\
\text { Haschka,W.K } \\
\text { ratz, F. } \\
\text { Schwenker, } \\
\text { G. } \\
\text { Palm,V.Homb } \\
\text { ach, and M. } \\
\text { Hoher }\end{array}$ & 1998 & $\begin{array}{l}\text { De-noising } \\
\text { of high- } \\
\text { resolution } \\
\text { ECG signals } \\
\text { by } \\
\text { combining } \\
\text { the discrete } \\
\text { wavelet } \\
\text { transform } \\
\text { with the } \\
\text { Wiener } \\
\text { filter. }\end{array}$ & $\begin{array}{l}\text { Combination } \\
\text { of the discrete } \\
\text { wavelet } \\
\text { transform and } \\
\text { the Wiener } \\
\text { filter to the } \\
\text { noise } \\
\text { reducing of } \\
\text { high } \\
\text { resolution } \\
\text { ECG signals. }\end{array}$ & $\begin{array}{l}\text { High } \\
\text { resolution } \\
\text { ECG } \\
\text { signals can } \\
\text { be easily } \\
\text { denoised. }\end{array}$ & $\begin{array}{l}\text { Improvement can be } \\
\text { present by the } \\
\text { selection of filter. }\end{array}$ \\
\hline 2 & $\begin{array}{l}\text { Alireza K } \\
\text { Ziarani, } \\
\text { Adaibert } \\
\text { Konrad. }\end{array}$ & 2002 & $\begin{array}{l}\text { Nonlinear } \\
\text { Adaptive } \\
\text { method of } \\
\text { elimination } \\
\text { of power } \\
\text { line } \\
\text { interference } \\
\text { in ECG } \\
\text { signals }\end{array}$ & $\begin{array}{l}\text { In this work, a } \\
\text { new signal } \\
\text { processing } \\
\text { algorithm is } \\
\text { introduced } \\
\text { (Adaptive } \\
\text { EMI filter). }\end{array}$ & $\begin{array}{l}\text { The } \\
\text { proposed } \\
\text { EMI filter } \\
\text { offers a } \\
\text { robust } \\
\text { structure } \\
\text { and provide } \\
\text { a high } \\
\text { degree of } \\
\text { immunity } \\
\text { with } \\
\text { respect to } \\
\text { external } \\
\text { noise. }\end{array}$ & $\begin{array}{l}\text { High degree of } \\
\text { immunity can be } \\
\text { improved by } \\
\text { improving the } \\
\text { construction of filter. }\end{array}$ \\
\hline 3 & $\begin{array}{l}\text { El-Sayed A. } \\
\text { El-Dahshan }\end{array}$ & 2011 & $\begin{array}{l}\text { Genetic } \\
\text { algorithm } \\
\text { and wavelet }\end{array}$ & $\begin{array}{l}\text { Hybrid } \\
\text { scheme of GA } \\
\text { and WT }\end{array}$ & $\begin{array}{l}\text { The } \\
\text { outcome of } \\
\text { this paper }\end{array}$ & $\begin{array}{l}\text { The noise reduction } \\
\text { of a signal } \\
\text { depends on the }\end{array}$ \\
\hline
\end{tabular}




\begin{tabular}{|c|c|c|c|c|c|c|}
\hline & & & $\begin{array}{l}\text { hybrid } \\
\text { schemem for } \\
\text { ecg signal } \\
\text { denoising }\end{array}$ & presented. & $\begin{array}{l}\text { shows that } \\
\text { the } \\
\text { obtained } \\
\text { performanc } \\
\text { e of } \\
\text { proposed } \\
\text { hybrid } \\
\text { scheme } \\
\text { using GA is } \\
\text { better than } \\
\text { the other } \\
\text { reported } \\
\text { wavelet } \\
\text { threshold } \\
\text { algorithm. }\end{array}$ & $\begin{array}{l}\text { optimum value of the } \\
\text { level of } \\
\text { decomposition, } \\
\text { the suitable forms of } \\
\text { wavelet family and } \\
\text { the thresholding } \\
\text { techniques. }\end{array}$ \\
\hline 4 & $\begin{array}{l}\text { K } \\
\text { Satyanaryana } \\
\text {, A.D Sarma, } \\
\text { P Naga } \\
\text { Praveen, M } \\
\text { Malini and D } \\
\text { Krishna } \\
\text { Reddy }\end{array}$ & 2013 & $\begin{array}{l}\text { Mitigation } \\
\text { of Cellular } \\
\text { Phone } \\
\text { Interference } \\
\text { in ECG } \\
\text { During } \\
\text { Emergency } \\
\text { Patient } \\
\text { Transportati } \\
\text { on }\end{array}$ & $\begin{array}{l}\text { Wavelet } \\
\text { transform, } \\
\text { least mean } \\
\text { squares, } \\
\text { normalized } \\
\text { least mean } \\
\text { squares and } \\
\text { recursive least } \\
\text { squares } \\
\text { algorithms }\end{array}$ & $\begin{array}{l}\text { Performanc } \\
\text { e of WT is } \\
\text { superior to } \\
\text { other } \\
\text { adaptive } \\
\text { algorithms } \\
\text { for } \\
\text { removing } \\
\text { the noise } \\
\text { from the } \\
\text { ECG } \\
\text { signal. }\end{array}$ & $\begin{array}{l}\text { WT with other } \\
\text { specifications can } \\
\text { also be applied on } \\
\text { signal and observe } \\
\text { the performance. }\end{array}$ \\
\hline 5 & $\begin{array}{l}\text { Prakruti J. } \\
\text { Joshi, Vivek } \\
\text { P. Patkar, } \\
\text { Akshay B. } \\
\text { Pawar, Prasad } \\
\text { B. Patil, Prof. } \\
\text { Bag al U. R., } \\
\text { Prof. Bipin D. } \\
\text { Mokal }\end{array}$ & 2013 & \begin{tabular}{l}
\multicolumn{1}{c}{ ECG } \\
denoising \\
using matlab
\end{tabular} & $\begin{array}{l}\text { A new filter } \\
\text { called as } \\
\text { moving } \\
\text { averaging } \\
\text { filter is } \\
\text { presented. }\end{array}$ & $\begin{array}{l}\text { Very good } \\
\text { efficiency } \\
\text { in } \\
\text { smoothing } \\
\text { out the } \\
\text { waveform } \\
\text { and } \\
\text { suppressing } \\
50 \text { Hz } \\
\text { power line } \\
\text { noise from } \\
\text { the original } \\
\text { ECG } \\
\text { signal. }\end{array}$ & $\begin{array}{l}\text { limitation of moving } \\
\text { averaging filter we } \\
\text { notice that it may } \\
\text { result in significant } \\
\text { amount of data loss if } \\
\text { number of points to } \\
\text { be averaged is not } \\
\text { optimum. }\end{array}$ \\
\hline 6 & $\begin{array}{l}\text { Galya } \\
\text { Georgieva- } \\
\text { Tsaneva, } \\
\text { Krassimir } \\
\text { Tcheshmedjie } \\
\text { v }\end{array}$ & 2013 & $\begin{array}{l}\text { Denoising of } \\
\text { Electrocardi } \\
\text { ogram Data } \\
\text { with } \\
\text { Methods of } \\
\text { Wavelet } \\
\text { Transform. }\end{array}$ & $\begin{array}{l}\text { An } \\
\text { improvement } \\
\text { of the } \\
\text { traditional } \\
\text { denoising } \\
\text { technique has } \\
\text { been } \\
\text { projected by } \\
\text { implementing } \\
\text { a new sub } \\
\text { band } \\
\text { dependent } \\
\text { threshold. }\end{array}$ & $\begin{array}{l}\text { The ECG } \\
\text { signal } \\
\text { corrupted } \\
\text { by the } \\
\text { power line } \\
\text { interference } \\
\text { is denoised } \\
\text { with LMS } \\
\text { adaptive } \\
\text { algorithm }\end{array}$ & $\begin{array}{l}\text { Further improvement } \\
\text { in threshold can also } \\
\text { be done. }\end{array}$ \\
\hline 7 & $\begin{array}{l}\text { Akanksha } \\
\text { Deo, DBV } \\
\text { Singh, Manoj } \\
\text { Kumar } \\
\text { Bandil, Dr. A } \\
\text { K Wadhwani }\end{array}$ & 2013 & $\begin{array}{l}\text { Denoising of } \\
\text { ECG Signals } \\
\text { with } \\
\text { Adaptive } \\
\text { Filtering } \\
\text { Algorithms } \\
\text { \& Patch } \\
\text { Based } \\
\text { Method. }\end{array}$ & $\begin{array}{l}\text { Least mean } \\
\text { square (LMS) } \\
\text { algorithm and } \\
\text { patch based } \\
\text { has been } \\
\text { implemented } \\
\text { for removing } \\
\text { the artifacts } \\
\text { from the ECG } \\
\text { signal. }\end{array}$ & & $\begin{array}{l}\text { In future, algorithm } \\
\text { with fast convergence } \\
\text { can be } \\
\text { developed for } \\
\text { denoising of ECG } \\
\text { signal since the LMS } \\
\text { adaptive } \\
\text { algorithm has slow } \\
\text { convergence. }\end{array}$ \\
\hline
\end{tabular}




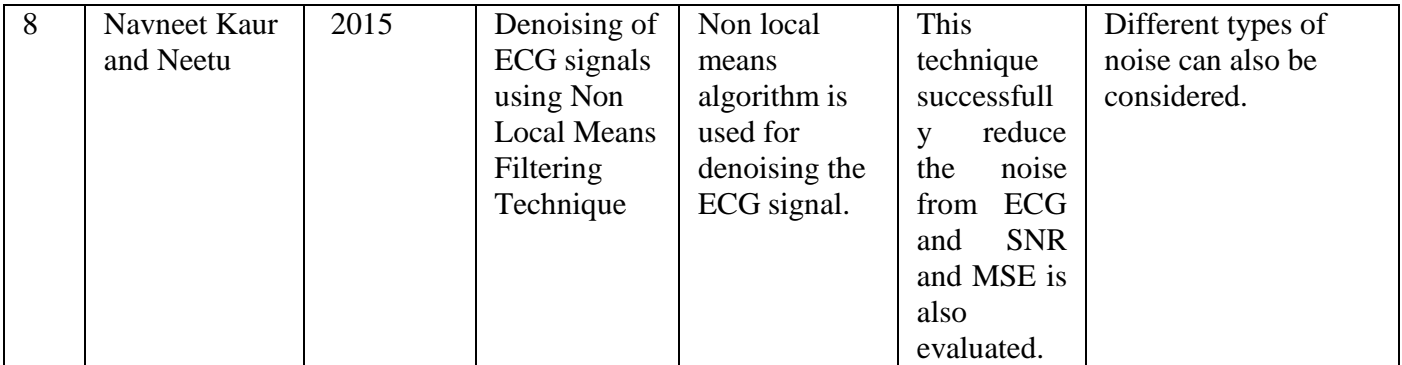

\section{DISCUSSION}

\subsection{Non linear Adaptive method of elimination of power line interference in ECG signals[3].}

In this paper, non-linear adaptive filtering method was implemented for mitigation of noise from the ECG signal. The result outcome of this paper was removal of power line interference from obtained ECG signal.

\subsection{ECG Denoising Using Matlab[5].}

In this study, various filtration methods were evaluated. The notch filter gives the best outcomes in removing the power line interference. The band pass filter removes the baseline wander and moving average filter was able in smoothing the signal. At some point it also reduced the power line interference to some extent

\subsection{Mitigation of Cellular Phone Interference in ECG During Emergency Patient Transportation [6].}

In this paper, pure ECG signal is generated and then by adding some random noise, noisy signal is obtained. Various noise reduction techniques like WT, LMS, NLMS and RLS were implemented and their outcomes have been evaluated in terms of quality and signal strength. It has been observed that WT bior5.5 is more effective than other techniques in case of high SNR. While in the case of low SNR the outcomes of wavelet transform is comparable to the outcomes of RLS algorithm. So the overall performance of WT is superior to other adaptive algorithms for removing the noise from the ECG signal.

\subsection{Denoising of Electrocardiogram Data} with Methods of Wavelet Transform[7].

In this paper, a new relationship has been introduced to find the adaptive threshold and verification of this threshold has been done on different ECG signals. Thus obtained outcomes show that this threshold is more suitable than traditional method and can be successfully applied on ECG signals.

\subsection{Denoising of ECG Signals with Adaptive Filtering Algorithms \& Patch Based Method [8].}

In this paper, the ECG signal corrupted by the power line interference is denoised with LMS adaptive algorithm. The patch based non local means method has also successfully removed the noise from the ECG signal. The LMS algorithm is easy to implement.

\subsection{Genetic algorithm and wavelet hybrid scheme for ECG signal denoising[9].}

The outcome of this paper shows that the obtained performance of proposed hybrid scheme using GA is better than the other reported wavelet threshold algorithms. The quality of denoised signal is more efficient for the medical diagnosis.

\subsection{De-noising of high-resolution ECG signals by combining the discrete wavelet transform with the Wiener filter[7].}

In this work, the comparison of known denoising algorithms on artificially generated ECG signals and on high resolution ECG signal degraded by noise, thus high resolution ECG signals can also be easily denoised.

\section{REFERENCES}

[1] R. Acharya, J. S. Suri, J. A.E. Spaan and S .M. Krishnan, "Advances in Cardiac Signal Processing", 2007 edition, Springer Berlin Heidelberg, New York, ISBN: 3-54036674-1.

[2] J. Moss and S. Stern., "Non-invasive electrocardiology: Clinical aspects of holter monitoring", 1st edition, 1996, W.B. Saunders, Philadelphia, ISBN: 9-7020-1925-9.

[3] Alireza K Ziarani, Adaibert Konrad, 'Non linear Adaptive method of elimination of power line interference in ECG signals', IEEE Transactions on Biomedical Engg, Vol.49, No.6, June 2002, pp. 540-544. (C) 2010 International Journal of Computer Applications (0975 - 8887) Volume 1- No.14 16.

[4] Mallat, S. G. A Wavelet Tour of Signal Processing (2 ed.). San Diego: Academic Press, 1999

[5] Prakruti J. Joshi, Vivek P. Patkar, Akshay B. Pawar, Prasad B. Patil, Prof. Bagal U. R., Prof. Bipin D. Mokal, " ECG Denoising Using MATLAB" International Journal of Scientific \& Engineering Research, Volume 4, Issue 5, May-2013 1401 ISSN 2229-5518

[6] K. Satyanarayana, A.D.Sarma, P.Naga Praveen, M. Malini, D. Krishna Reddy," Mitigation of Cellular Phone Interference in ECG During Emergency Patient Transportation" Cardiovascular Engineering and Technology, Vol. 4, No. 4, December 2013 (_ 2013) pp. 544-552 DOI: 10.1007/s13239-013-0159.

[7] Galya Georgieva-Tsaneva, Krassimir Tcheshmedjiev,"Denoising of Electrocardiogram Data with Methods of Wavelet Transform 'InternationalConference on Computer Systems and Technologies - CompSysTech'13.

[8] Akanksha Deo, DBV Singh, Manoj Kumar Bandil, Dr. A K Wadhwani," Denoising of ECG Signals with AdaptiveFiltering Algorithms \& Patch Based Method" IRACST - International Journal of Computer Networks and Wireless Communications (IJCNWC), ISSN: 22503501 Vol.3, No3, June 2013. 
[9] E.-S. A. El-Dahshan,"Genetic algorithm and wavelet hybrid scheme for ECG signal denoising" Telecommun. Syst., vol. 46, no. 3, pp. 209-215, Mar. 2011.

[10] H. A.Kestler,M.Haschka,W.Kratz，F. Schwenker， G. Palm,V.Hombach, and M. Hoher,'De-noising of highresolution ECG signals by combining the discrete wavelet transform with the Wiener filter" Comput. Cardiol., vol. 25, pp. 233-236, Sep. 1998.

[11] J.T.Catalano, (2002), Guide to ECG Analysis, 2nd edition, Lippincott Williams \& Wilkins, Philadelphia, ISBN-0-7817-2930-0.

[12] J. Moss, S. Stern, (1996), Non-invasive electrocardiology: Clinical aspects of holter monitoring, 1st edition, W.B. Saunders, Philadelphia, ISBN: 9-70201925-9.

[13] P. E. McSharry, G. D. Clifford, L. Tarassenko,L. A. Smith, (2003), A dynamical model for generating synthetic elctrocardiogram signals, IEEE Transactions on Biomedical Engineering, vol. 50, no.3, pp.289-294.

[14] Acharya, R., Bhat, P. S., Iyengar, S. S., Roo, A.Dua, (2002), Classification of heart rate data using artificial neural network and Fuzzy equivalence relation, The Journal of the Pattern Recognition Society.

[15] E. N. Bruce, (2001), Biomedical Signal Processing and Signal Modeling. New York: Wiley. 